http://ejournal.upi.edu/index.php/jaz - e-mail: jurnal_zonasi@upi.edu doi.org/10.17509/jaz.v4i2.30950

\title{
ORNAMEN TRADISIONAL BALI PADA INTERIOR BANGUNAN GEDUNG KSIRARNAWA TAMAN BUDAYA BALI
}

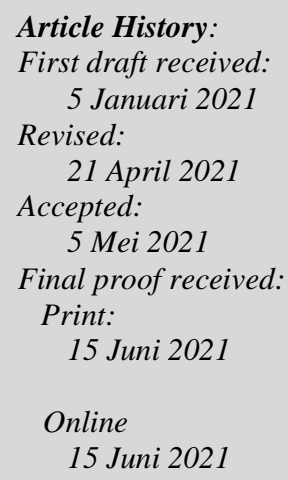

Jurnal Arsitektur ZONASI is indexed and listed in several databases:

SINTA 4 (Arjuna)

GARUDA (Garda Rujukan Digital) Google Scholar

Dimensions

oneSearch

BASE

Member:

Crossref

RJI

APTARI

FJA (Forum Jurna Arsitektur)

IAI

AJPKM

\author{
Ni Wayan Ardiarani Utami ${ }^{1}$ \\ Ni Luh Gede Niti Swari ${ }^{2}$ \\ 1,2 Institut Desain dan Bisnis Bali, Denpasar, Indonesia \\ Denpasar, Bali \\ Email: ardiarani.utami@std-bali.ac.id \\ Nitiswari@std-bali.ac.id
}

\begin{abstract}
The variety of ornaments in Traditional Balinese Architecture is divided into two, namely ornaments and decorations. Ornaments are part of a variety of ornaments whose existence sticks to the decorated part and tends to be permanent in nature. Examples of ornaments are Pepatran, Kekarangan, Lelengisan, etc. Ornaments on buildings, made and placed not only with harmony, beauty of shapes, fine carving but also looking at norms, literature and mythology that are believed to be true. There are also patterned face masks in traditional Balinese architectural ornaments art, which are commonly embedded on natural stone, red brick or wood materials and placed in certain positions. Bali Province Cultural Park as one of the arts centers of Bali Province which is expected to adopt a positive element of outside cultural art as well as ward off negative elements so that Balinese cultural art can grow sustainably throughout the time. But until now there has been no research that has examined in depth the traditional Balinese ornaments in the Bali Province Cultural Park, especially in the interior ornaments. This study uses qualitative descriptive methods, to reveal the type of Balinese traditional ornaments used on the interior of Ksirarnawa Building, so that it can be used as a reference again to other researchers related to ornamental variety. In the interior of the Ksirarnawa building, it features more ornaments made with philosophical values from mythology that are believed to be true behind it, namely according to the story of Mount Mandhara and the ornaments that were formed to beautify the interior of the building and have traditional Balinese characteristics.
\end{abstract}

Keywords: interior design, traditional Balinese ornaments, Ksirarnawa Building

Abstrak: Ragam hias pada Arsitektur Tradisional Bali terbagi menjadi dua, yaitu ornamen dan dekorasi. Ornamen adalah bagian dari ragam hias yang keberadaannya menempel pada bagian yang dihias dan cenderung permanen sifatnya. Contoh ornamen adalah Pepatran, Kekarangan, Lelengisan, dll. Ornamen atau ragam hias pada bangunan, dibuat dan ditempatkan bukan saja dengan keserasian, keindahan bentuk, halusnya ukiran tapi juga melihat norma, kepustakaan maupun mitologi yang diyakini kebenarannya. Ornamen dalam seni arsitektur tradisional Bali ada juga yang bermotif kedok wajah, dimana secara lazim dipahat pada material batu alam, bata merah atau kayu dan diletakkan pada tempat-tempat tertentu. Taman Budaya Provinsi Bali sebagai salah satu pusat kesenian Provinsi Bali, diharapkan untuk dapat mengadopsi unsur positif seni budaya luar serta menangkal unsur negatifnya, sehingga seni budaya Bali dapat dilestarikan sepanjang masa. Sampai saat ini belum ada penelitian yang mengkaji secara mendalam mengenai ornamen-ornamen tradisional Bali yang ada di dalam Taman Budaya Provinsi Bali, khususnya pada ornament interiornya. Penelitian ini menggunakan metode deskriptif kualitatif, untuk mengungkapkan jenis ornamen tradisonal Bali yang digunakan pada interior Bangunan Ksirarnawa, sehingga dapat digunakan sebagai referensi lagi untuk peneliti lain terkait ragam hias. Pada interior bangunan Gedung Ksirarnawa ini lebih banyak menonjolkan ornamen yang dibuat dengan nilai filosofis dari mitologi yang diyakini kebenararan di baliknya, yaitu sesuai cerita pemutaran Gunung Mandhara dan ornamen yang dibentuk untuk menjadikan indah interior bangunan dan berciri khas Tradisonal Bali.

Kata Kunci: desain interior, ornamen tradisional Bali, Gedung Ksirarnawa. 


\section{Pendahuluan}

Provinsi Bali merupakan salah satu daerah di Indonesia yang sarat akan kekayaan ragam hias pada arsitektur tradisionalnya. Ragam hias pada arsitektur tradisional Bali dibagi menjadi dua, yaitu ornamen dan dekorasi (Gelebet, dkk, 1986). Ornamen adalah bagian dari ragam hias yang keberadaannya menempel pada bagian yang dihias dan cenderung permanen sifatnya, sedangkan dekorasi adalah bagian dari ragam hias yang letaknya bisa dibongkar pasang atau dipindah sesuai keperluan. Contoh ornamen adalah Pepatran, Kekarangan, Lelengisan, dll. Contoh dekorasi adalah patung, lukisan, arca, dll. Keberadaan ragam hias khususnya ornamen menjadi wajib dalam setiap bangunan yang dibangun di Bali, dengan adanya Perda No 5 Tentang 2005 tentang Arsitektur Tradisional Bali. Perda tersebut mengatur tentang persyaratan tampilan Arsitektur Tradisional Bali pada wujud bangunannya serta bertujuan untuk mewujudkan bangunan gedung dengan motif dan ciri khas Arsitektur Tradisional Bali secara umum maupun corak arsitektur setempat yang selaras dengan lingkungannya (Peraturan Daerah Provinsi Bali Nomor 5 Tahun 2005 Tentang Persyaratan Arsitektur Bangunan Gedung, 2005)

Taman Budaya sebagai salah satu pusat kesenian Provinsi Bali diharapkan dapat mengambil unsur baik seni budaya dari luar serta menangkal unsur kurang baiknya sehingga seni budaya Bali dapat lestari sepanjang masa (U. T. B. Bali, 2016). Taman Budaya ini memiliki lima kawasan suci, tiga gedung, lima panggung terbuka/kalangan, dan dua studio. Tiga Gedung yang ada di tempat ini yaitu: Gedung Pameran Utama, Mahudara Mandara Giri Bhuvana dengan luas 800 m2; Gedung Krya Sembrani Occihcrawa seluas 300 m2; dan Gedung Ksirarnawa dengan luas $5.500 \mathrm{~m} 2$. Salah satu bangunan yang menonjol pada Taman Budaya Provinsi Bali adalah Bangunan Gedung Ksirarnawa yang biasanya digunakan untuk pameran dan pertunjukan kesenian kolosal pada ruangan tertutup. Gedung ini terdiri atas dua lantai, dengan penggunaan lantai atas sebagai tempat pertunjukan, seminar, konferensi serta pertemuan lainnya dan lantai bawah untuk perkantoran, pameran seni lukis dan kelompok pengerajin.

Pembahasan pada penelitian ini lebih menitikberatkan pada tampilan ornamen yang digunakan di dalam interior Bangunan Ksirarnawa. Adapun rumusan masalah utama pada penelitian ini adalah bagaimana tampilan ornamen interior pada bangunan Gedung Ksirarnawa Taman Budaya. Penelitian ini dimaksudkan untuk menambah literatur lainnya terkait keberadaan ornamen pada interior bangunan, karena penelitan yang sudah pernah ditulis lebih banyak membahas tentang ornamen pada eksterior bangunan, seperti Ornament Bermotif Kedok Wajah (Suryada, 2014), Pemaknaan Ornamen Murdha (Paramadhyaksa, 2009), Studi Multikultural pada Ornamen Bali (Maharlika, 2018). Selain itu juga bertujuan untuk mengiventarisasi ornamen apa saja yang ada di Bangunan Gedung Ksirarnawa sebagai salah satu bangunan pusat kebudayaan Bali.

\section{Tinjauan Pustaka}

Para ahli berpendapat Ornamen berasal dari bahasa Yunani dari kata "ornare" yang artinya menghias, hiasan atau perhiasan. Pengertian ornamen menurut Gustami (Sunaryo, Aryo. 2009. Ornamen Nusantara. Semarang: Dahara Press. - Penelusuran Google, n.d.), yaitu komponen produk seni ditambahkan atau sengaja dibuat untuk tujuan sebagai hiasan. Menurut Triyanto (Iswati, 2016), secara fisik seni ornamen memiliki fungsi menghiasi suatu benda atau barang sehingga menjadikan benda atau barang itu menjadi tampak bernilai indah, 
berharga, dan bermakna. Secara garis besar dapat disimpulkan ornamen memberikan tujuan yang erat kaitannya dengan estetika dalam kehidupan manusia.

Menurut Gelebet (Gelebet, dkk, 1986:332) ragam hias pada bagian bangunan atau peralatan dan perlengkapan bangunan dari jenis-jenis flora dinamakan sesuai jenis dan keadaannya. Dibagi menjadi tiga, yaitu Keketusan (1), Kekarangan (2), Pepatraan (3). Keketusan menggunakan sebagian terpenting dari tumbuh-tumbuhan yang dipolakan berulang dengan pengolahan untuk memperindah penonjolannya. Ada beberapa jenis keketusan, yaitu keketusan wangga (1) yang melukiskan bunga-bunga besar besar yang mekar dari jenis berdaun lebar dengan lengkung-lengkung keindahan umumnya ditatahkan pada bidang-bidang luas atau peperadaan lukisan cat perada warna emas pada lembar kain hiasan. Keketusan bunga tuwung(2) merupakan hiasan berpola bunga terung dipolakan dalam bnetuk liku-liku segi banyak berulang atau bertumpuk menyerupai bentuk bunga terung. Keketusan bun-bunan(3), hiasan berpola tumbuh-tumbuhan jalar atau jalar bersulur, memperilhatkan jajar-jajar jalaran dan sulur-sulur di sela-sela bunga-bunga dan dedaunan.

Kekarangan menampilkan suatu bentuk hiasan dengan suatu karangan atau rancangan yang berusaha mendekati bentuk-bentuk flora yang ada dengan penekanan pada bagian keindahan. Ada beberapa jenis karang yaitu: karang simbar(1) yang merupakan suatu hiasan rancangan yang mendekati atau serupa dengan tumbuhtumbuhan lekar dengan daun terurai ke bawah yang namanya simbar manjangan, biasanya dipakai untuk hiasan sudut bebaturan dibagian atas pada pasangan batu atau tatahan kertas pada bangunan bade wadah, bukur atau hiasan sementara lainnya. Karang bunga (2) adalah suatu hiasan rancangan yang berbentuk bunga dengan kelopak dan seberkas daun dan digunakan juga untuk hiasan sudut-sudut bebaturan atau hiasan penjolan bidang-bidang. Karang suring(3) merupakan suatu hiasan yang menyerupai serumpun perdu dalam bentuk kubus yang difungsikan untuk sendi alas tiang tugeh (singa bersayap atau garuda)

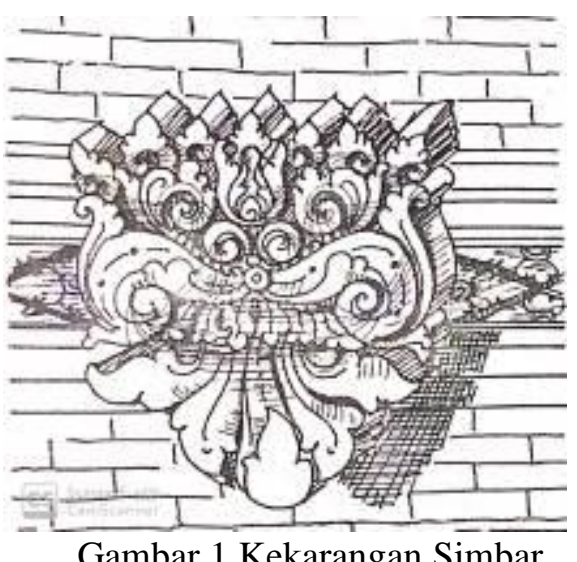

Gambar 1 Kekarangan Simbar

Sumber Gelebet, 1986

Pepatraan merupakan gubahan keindahan hiasan dalam patern-patern yang disebut patra atau pepatraan. Pepatraan juga banyak mengambil bentuk flora sehingga dinamai dengan jenis flora yang diwujudkan. Diwujudkan dalam pola yang berulang dan dapat pula dalam pola berkembang. Masing-masing patra memiliki identitas yang kuat dari segi tampilan sehingga mudah untuk dikenali. Ada beberapa jenis patra, yaitu: Patra Wangga (1) merupakan kembang mekar atau kuncup dengan daun-daun lebar divariasi lengkunglengkung, batang-batang bersulur disela-sela bawah bunga dan daun-daun. Patra Sari (2) berbentuk menyerupai flora dari jenis berbatang jalar melingkar-lingkar yang berulang, dengan menonjolkan sari bunga. Daun-daun dan bunga-bunga dilukiskan dengan patern-patern yang diperindah, umumnya digunakan pada 
bidang lebar. Patra Bun-bunan(3), dipolakan berulang antara daun dan bunga dirangkai batang jalar. Patra Pidpid (4) melukiskan flora dari jenis daun bertulan tengah dengan daun-daun simetris dan dilukiskan pada bidang sempit. Patra Punggel (5) mengambil bentuk dasar liking paku, yaitu sejenis flora dengan lengkunglengkung daun muda pohon paku, dipolakan berulang dengan lengkung timbal balik. Selain digunakan utuh, digunakan juga sebagai pelengkap bentuk kekarangan (patra dari jenis fauna). Patra Samblung (6) merupakan pohon menjalar dengan daun-daun lebar dipolakan dalam bentuk patern. Dapat berupa ujung-ujung pohon jalar melengkung dengan kelopak daun dan daun-daun dihias lengkung-lengkung harmonis. Patra Pae (7) menggunakan bentuk tumbuh-tumbuhan sejenis kapu-kapu yang dipolakan berulang dalam bentuk memanjang. Patra Ganggong (8) mengambil bentuk tumbuhan ganggang air yang dipolakan dalam bentuk berulang berjajar memanjang. Patra Batun Timun(9) memakai biji mentimun yang dipolakan dalam susunan diagonal berulang, dengan sela-sela susunan dihias dengan bentuk patra mas-masan setengah bidang. Patra Sulur (10) melukiskan pohon jalar jenis beruas dengan daun sulur bercabang tersusun berulang, biasanya dalam bentuk tiga jalur batang jalur teranyam berulang. Patra Bun dengan motif (11) menggunakan bentuk dasar yang menyerupai patra wangga, patra punggel, patra sari, patra samblung. Bentuk divariasi dengan motif cerita pewayangan, rakyat dan dunia fauna ataupun gabungan.

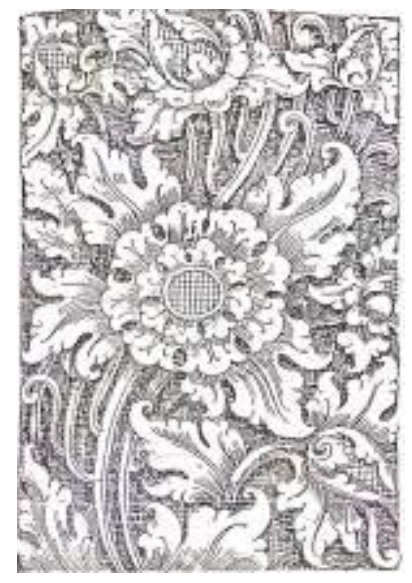

Gambar 2 Patra Wangga

Sumber: Suparta, 2010

Beberapa karakter dari pepatraan menurut Uthama (Uthama, 2015) yaitu menjalar, realistis, bidang datar/plat, dua dimensi, ornamental/ non struktural, dan mudah dipahami. Pepatraan ini mudah dimengerti, dan berfungsi untuk memperindah serta memperkuat ciri khas bangunan. Ornamen dalam seni arsitektur tradisional Bali ada juga yang bermotif kedok wajah, dimana lazim dipahatkan pada material batu alam, bata merah atau kayu dan ditempatkan pada posisi tertentu (Suryada, 2014), antara lain: Karang bhoma, Karang Sae, Karang Bentolu, Karang Tapel, Karang manuk dan Karang Hasti.

\section{Metode Penelitian}

Lokasi dari penelitian adalah di Kota Denpasar, yaitu di Taman Budaya Provinsi Bali (Art Centre), yang berlokasi pada Jalan Nusa Indah, wilayah Desa Sumerta Kelod, Kecamatan Denpasar Timur. Penelitian akan difokuskan pada salah satu bangunan yang terdapat pada Taman Budaya Provinsi Bali (Art Centre), yaitu Gedung Ksirarnawa dengan luas $5.500 \mathrm{~m} 2$. Bangunan ini merupakan salah satu bangunan yang menonjol yang biasanya digunakan untuk pameran dan pertunjukan kesenian kolosal pada ruangan tertutup. 
Penelitian ini dilakukan dengan observasi secara langsung pada Bangunan Ksirarnawa untuk memperoleh data-data fisik lapangan seperti data eksisting lapangan dan foto-foto dokumentasi pada saat penelitian berlangsung. Selain itu, pada penelitian ini wawancara dilakukan secara langsung dengan pihak pengelola Taman Budaya Provinsi Bali (Art Centre) untuk memperoleh data-data nonfisik mengenai sejarah, civitas, kapasitas, serta aktivitas yang berlangsung pada Gedung Ksirarnawa. Pada penelitian ini terdapat 2 macam variable penelitian antara lain: Variabel Bebas (Independent) yaitu berupa Ornamen Arsitektur Bali, dan Variabel Terikat (Dependen) yaitu berupa bentuk, perletakan, serta detail ornamen-ornamen Arsitektur Bali yang terdapat pada bangunan Gedung Ksirarnawa.

Penelitian ini memakai metode deskriptif kualitatif. Penelitian kualitatif bertujuan untuk mengerti peristiwa yang dirasakan oleh subjek penelitian terkait dengan perilaku, persepsi, motivasi, tindakan secara keseluruhan dengan menggunakan narasi dalam bentuk rangkaian kalimat menjadi paragraf. (Moleong, 2017). Dengan menggunakan metode ini, peneliti memanfaatkan data-data kualitatif yang telah didapat dari proses pengumpulan data yang kemudian dijabarkan secara deskriptif, yaitu dengan cara mendeskripsikan variabelvariabel yang ada pada penelitian ini. Metode penelitian ini digunakan untuk mengungkapkan jenis ornamen tradisonal Bali yang digunakan pada interior Bangunan Gedung Ksirarnawa, sehingga dapat digunakan sebagai referensi lagi untuk peneliti lain terkait ragam hias.

\section{Hasil dan Pembahasan}

Gedung Ksirarnawa berasal dari Bahasa Sansekerta dengan arti lautan susu, dengan mengambil inspirasi cerita perputaran Gunung Mandhara di Lautan/Ksirarnawa. (UPT. Taman Budaya Provinsi Bali, 2016). Cerita Adi Parwa (Suteja, 2017), mengisahkan pemutaran Gunung Mandhara di lautan susu yang disebut dengan Ksirsrnawa serta dilakukan oleh para Dewa dan Daitya-Raksasa, mengeluarkan minyak, Arda candra (bulan sabit), Dewi Sri, Dewi Laksmi, Kuda Ucchaiswara, Kastubhamani (permata), dan Danwantari yang membawa Swetakamandalu berisi Tirtha Kamandalu (air suci). Berdasarkan hal ini, sebagian besar ornamen yang ada pada interior bangunan Gedung Ksirarnawa menggunakan ornamen sesuai dengan cerita tersebut.

Bangunan Gedung Ksirarnawa ini dirancang oleh arsitektur termuka Bali yakni Ida Bagus Tugur pada tahun 1986. Rancangan bangunan Gedung Ksirarnawa ini sangat bernafaskan Arsitektur Tradisional Bali, hal ini dapat dilihat dari tampilan depan bangunan dengan kori agung berparas bata merah dan diapit naga pada kedua sisi tangga untuk akses masuk ke lantai atas.

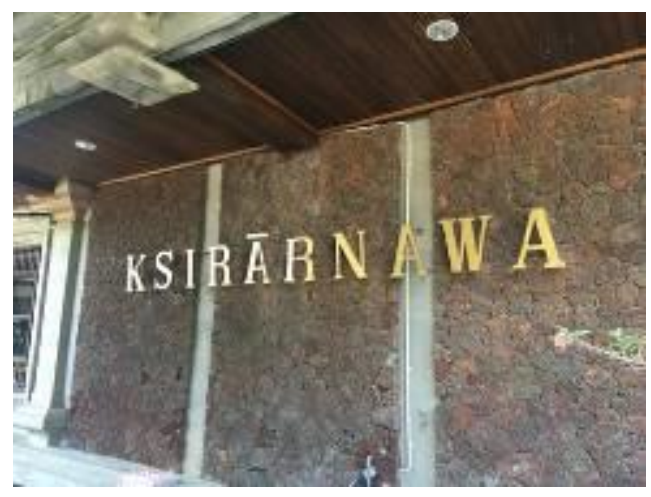

Gambar 3. Gedung Ksirarnawa

Sumber: Utami, 2020 


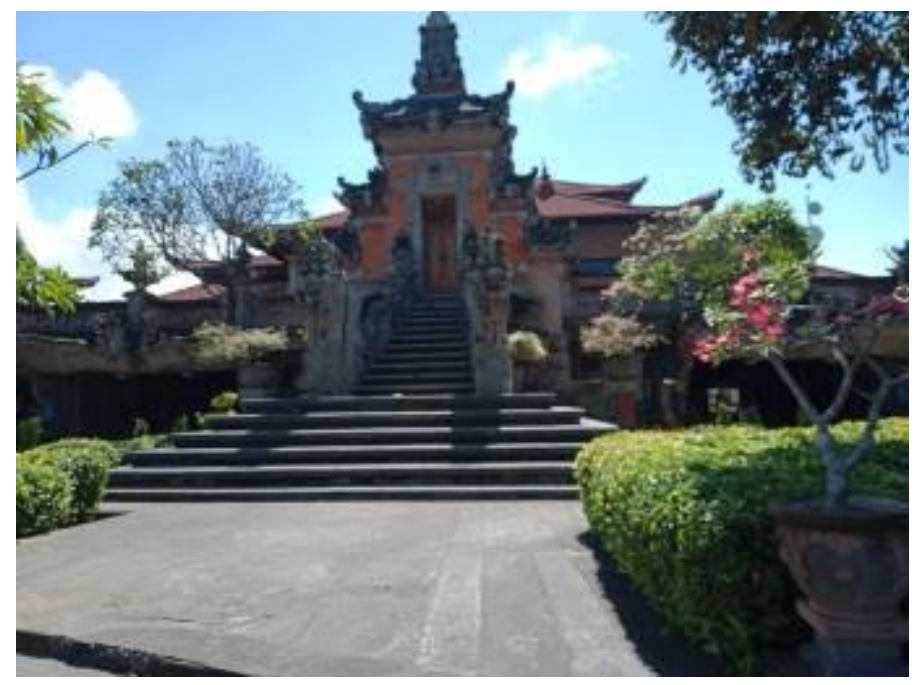

Gambar 4. Tampilan Depan bangunan Gedung Ksirarnawa Sumber: Swari, 2020

Pada keempat pintu masuk bangunan Gedung Ksirarnawa ini dilengkapi dengan ornamen Arsitektur Tradisional Bali berbentuk burung Garuda pada bagian atas dan diapit oleh raksasa pada kedua sisinya sebagai penyambutan untuk orang yang akan masuk ke dalam bangunan. Ornamen burung Garuda tersebut diukir dengan sayap yang mengembang lebar dan kedua cakar serta kepala menghadap kedepan. Ornamen ini termasuk dalam kekarangan yang bermotif kedok wajah, hanya saja untuk hal ini berwujud seekor burung Garuda. Pemiliihan bentuk burung Garuda berkaitan dengan cerita dari pemutaran Gunung Mandhara, hal ini sesuai hasil wawancara dengan Ida Bagus yadnya, yaitu Putra dari Ida Bagus Tugur (Arsitek Gedung Ksirarnawa) sekaligus seorang arsitek yang menyatakan bahwa ayahanda beliau biasanya dalam merancang bangunan, menitikberatkan pada filosofi yang menjadi konsep dasar perancangan bangunan tersebut. Semua ornamen yang dibuat pasti memiliki filosofi dibaliknya. Ornamen raksasa yang diukir berbentuk secara utuh dari kepala hingga kaki, dengan gigi dan taring yang tajam, mata melotot dan ukiran pada pakaian serta perhiasannya. Raksasa ini digambarkan sedang memegang ekor naga pada tangan satu dan tangan yang lainnya mengepal. Patung raksasa ini memiliki filosofis yaitu Detya-Raksasa yang sedang memegang Naga Basuki untuk memutar Gunung Mandhara.

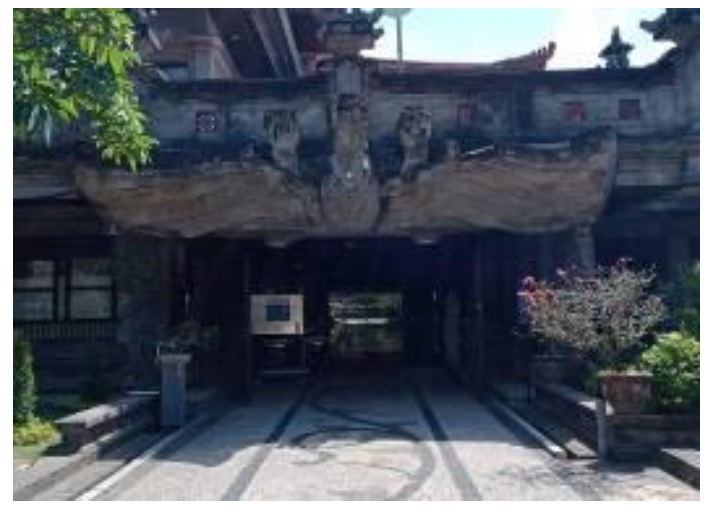

Gambar 5. Ornamen Burung Sumber: Swari, 2020

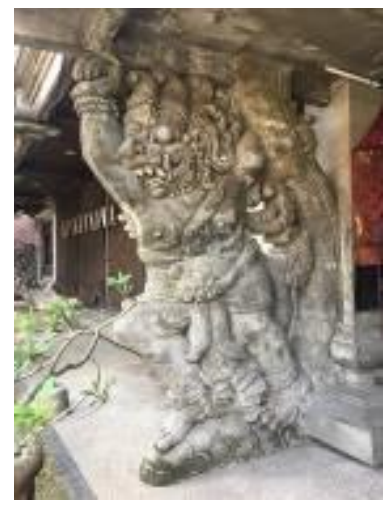

Gambar 6. Ornamen Raksasa Sumber Utami, 2020

Pada lantai bawah bangunan Gedung Ksirarnawa terdapat perkantoran pada bagian timur dan tempat pameran seni lukis kelompok pengerajin pada bagian barat. Dibagian tengah terdapat kolam air berbentuk 
mandala. Sesaat setelah masuk ke dalam bangunan, akan terlihat ornamen pada dinding yang sekaligus berfungsi sebagai loster tempat udara mengalir. Ornamen ini berbentuk persegi panjang dengan dua corak. Corak bagian atas dan bawah berwarna abu dengan motif memanjang dan corak pada bagian tengah dengan warna bata merah dan berbentuk mandala. Ornamen ini terdapat pada keempat pintu masuk di dinding yang berhubungan dengan sisi luar. Ornamen ini melambangkan Gunung Mandhara yang akan diputar nantinya.

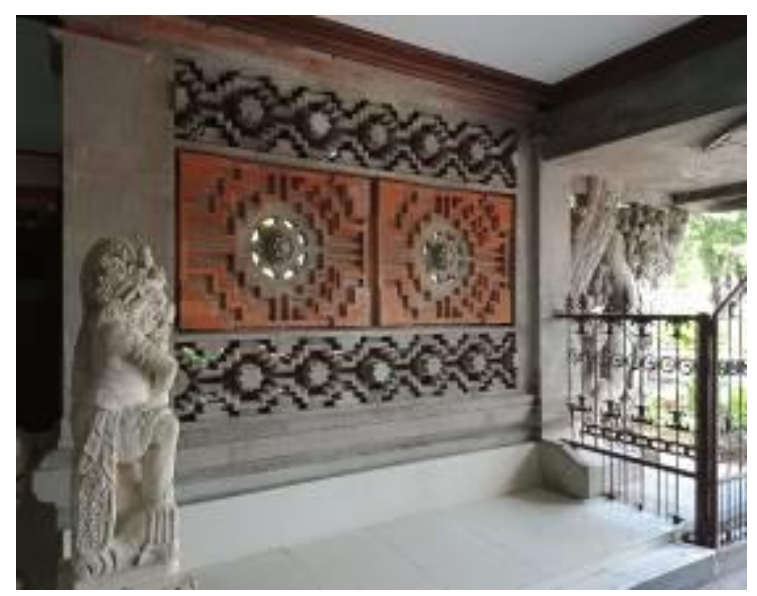

Gambar 7. Ornamen pada dinding

Sumber: Swari, 2020

Pada tiang bangunan terdapat beberapa ornamen, tapi hanya dari bagian tengah sampai atas. Pada bagian tengah terdapat ornamen tumbuhan lengkap dengan bunga dan daun serta sulur yang diukir memanjang secara vertikal dengan diapit kayu pada kedua sisinya, dengan dicat berwarna emas dan dasar berwarna merah. Ornamen ini termasuk Patra Sari apabila dilihat dari bentuk dan coraknya. Dibagian atas tiang juga terdapat ukiran menyerupai bunga teratai dengan posisi terbalik dan menyelubungi semua sisi tiang.
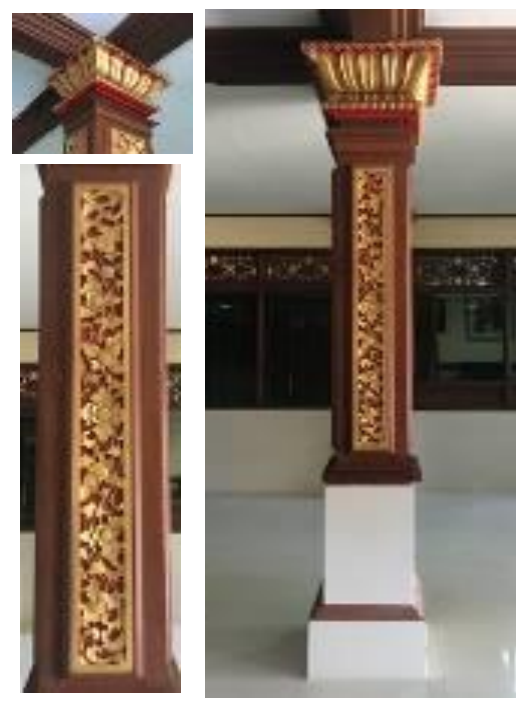

Gambar 8. Ornamen pada tiang

Sumber: Utami, 2021

Dibagian tengah bangunan terdapat kolam berbentuk mandala yang diibaratkan sebagai lautan (Ksirarnawa) itu sendiri dengan patung Dewi Sri, Dewi Laksmi dan Kuda Ucchaiswara pada bagian tengah kolam diatas air mancur. Patung Dewi-dewi dan kuda memiliki nilai filosofis yaitu hasil dari perputaran Gunung Mandhara. 


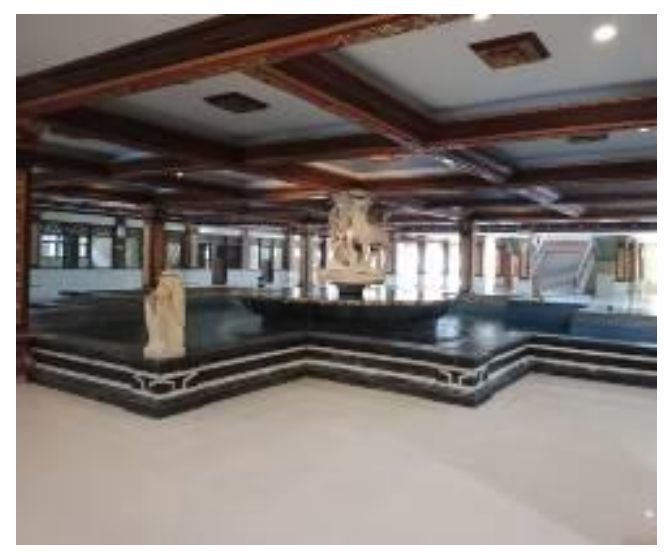

Gambar 9. Kolam berbentuk mandala Sumber: Swari, 2020

Pada bagian plafond diatas kolam terdapat ornamen tanaman yang lengkap dengan bunga, daun dan sulur. Bentuk dari ornamen tersebut sama dengan ornamen pada tiang yang ada, serta warna emas dan dasar berwarna merah. Ornamen ini bisa dikelompokan dalam jenis Patra Sari, tapi untuk ornamen pada bagian tengah dapat dikelompokan menjadi Patra Wangga, karena terdiri dari bunga yang mekar dengan daun-daun lebar divariasi lengkung.
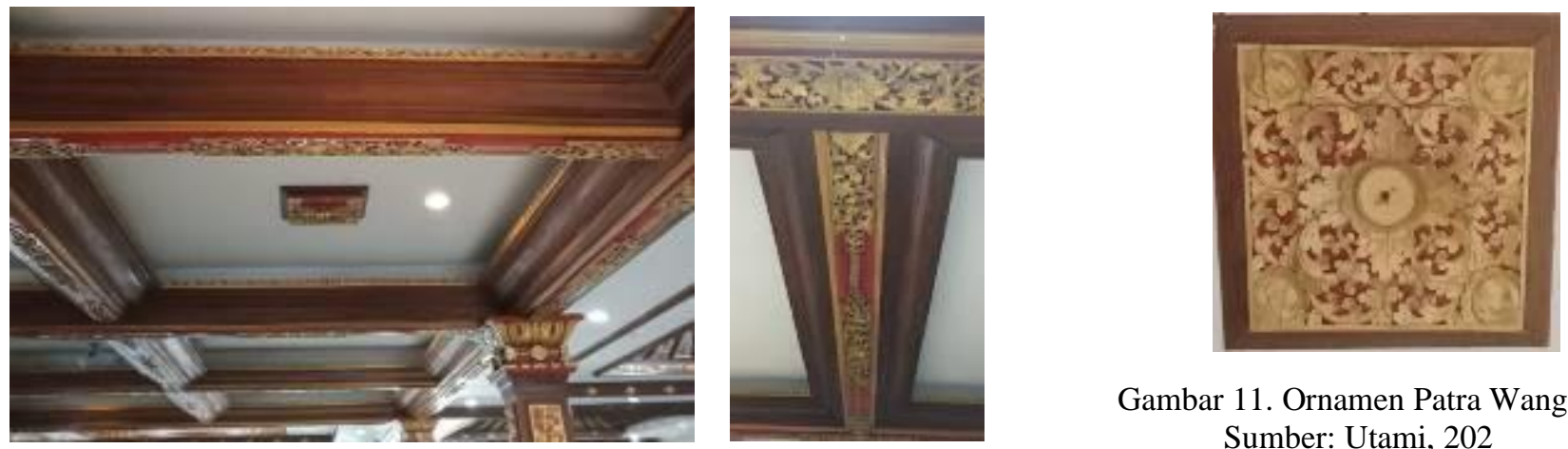

Gambar 10. Ornamen Patra Sari pada flapon diatas kolam

Gambar 11. Ornamen Patra Wangga Sumber: Utami, 202 Sumber: Swari, 2020

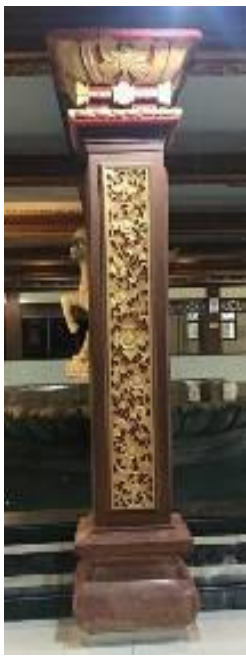

Ornamen yang ada pada tiang disekitar kolam agak sedkit berbeda dengan tiang lainnya dari segi ukuran, dimana ornamen dibagian ini diukir lebih besar daripada tiang lainnya. Pada bagian atas tiang juga terlihat ornamen yang berbeda, yaitu berbentuk hewan serangga dengan tanaman disisinya. Ornamen pada tiang ini dapat masukan dalam Patra Wangga yang terlihat dari gambar bunga yang sedang mekar dengan daun-daun lebar divariasi lengkung-lengkung.

Pada bagian plafond lantai bawah juga terdapat ornamen berupa tanaman dengan bentuk memanjang dengan daun dan sulur tanpa bunga, untuk bagian ini termasuk Patra Punggel, karena diletakan berulang dan tanpa bunga. Ornamen bunga terdapat dibagian agak bawah yang bersambung dengan bentuk wajik, ornamen ini termasuk gabungan antara Patra Sari dengan Patra Mas-Masan. 


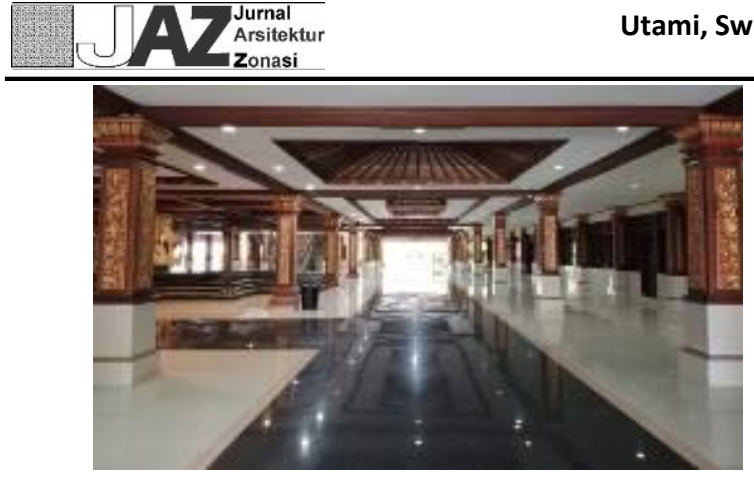

Gambar 13. Suasana interior lantai bawah Sumber: Swari, 2020

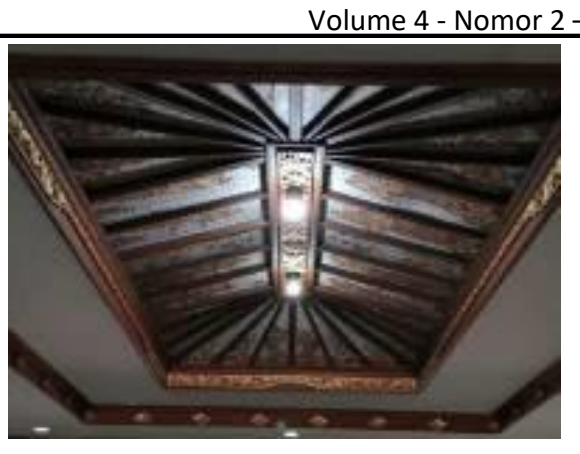

Gambar 14. Detail ornament Patra Sari dan Patra Mas-Masan pada plafond

Sumber: Swari, 2020

Dibagian tangga yang menghubungkan ke lantai atas, terdapat railing dengan ornamen berbentuk tanaman. Tanaman ini memiliki bunga lengkap dengan daun dan sulur, dengan ornamen berwarna emas dan dasar berwarna merah. Ornamen ini dapat dimasukan dalam Patra Wangga karena memiliki bunga yang mekar, dengan daun-daun lebar divariasi lengkung.

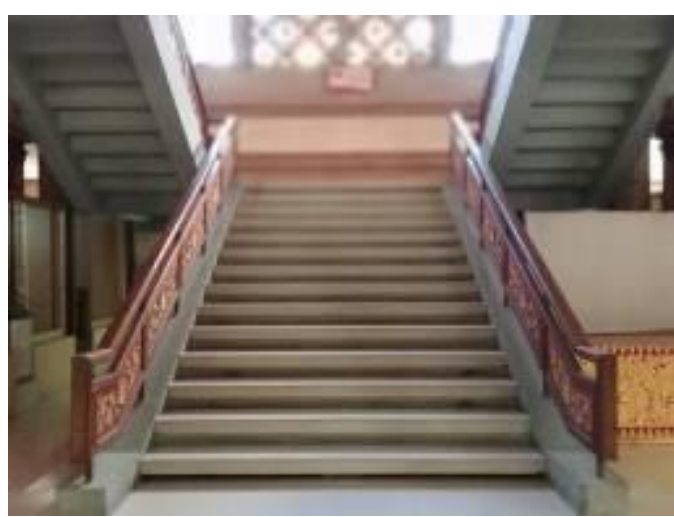

Gambar 15. Tangga

Sumber: Swari, 2020

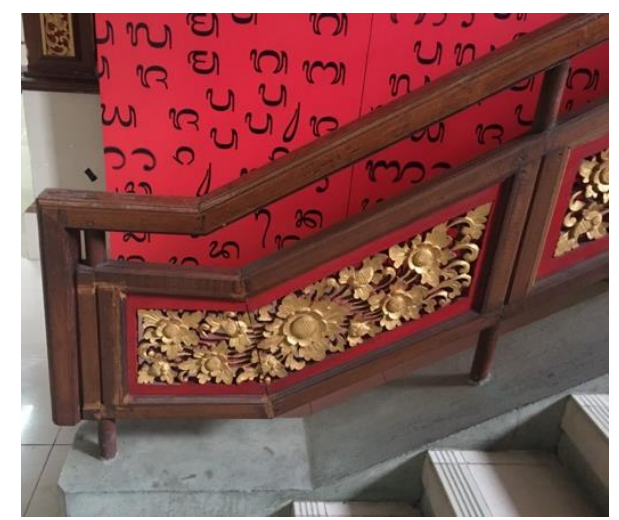

Gambar 16. Ornamen Patra Wangga

Sumber: Utami, 2020

Pada lantai atas bangunan Gedung Ksirarnawa ini menampung 525 orang dalam sekali acara dan dapat dipergunakan untuk tempat pertunjukan, seminar, konferensi serta pertemuan lainnya. Pada bagian ini, selain ruang interior yang dilengkapi dengan dua kamar kecil, juga terdapat empat Bale Bengong disetiap sudut bagian eksterior.

Pada bordes tangga menuju ke lantai atas, terdapat berbagai jenis ornamen. Yang pertama terlihat adalah ornamen dengan motif tanaman bersulur dikedua sisinya, dan beberapa kembang yang sedang mekar serta berbentuk memanjang berwarna putih. Ornamen ini terletak pada dinding bagian selatan dibagian bordes dibawah loster. Jika dilihat dari bentuk penyusun ornamennya, ornamen ini termasuk Patra Wangga.

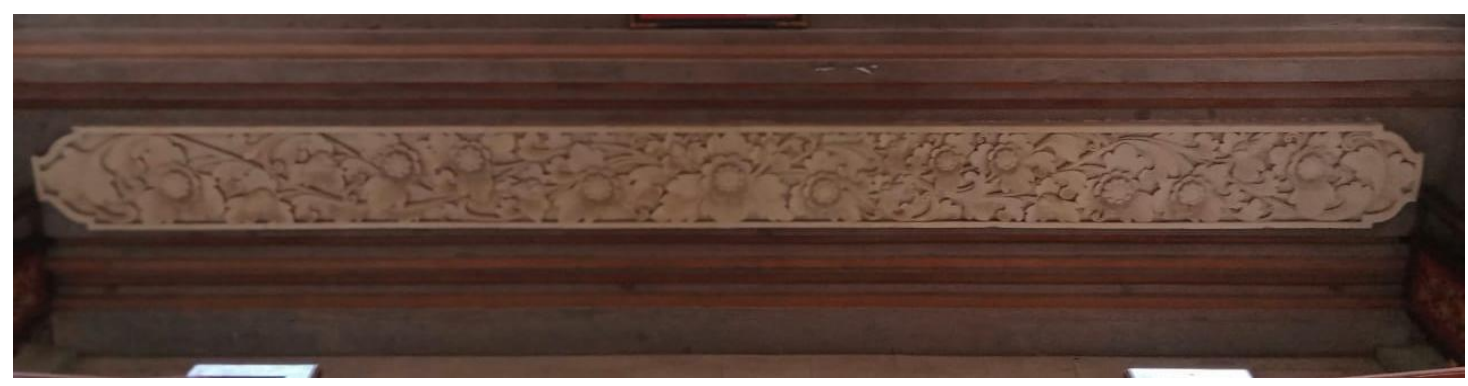

Gambar 16. Ornamen di dinding selatan bawah pada bordes.

Sumber: Swari, 202 
Pada bagian atas ornamen Patra Wangga tersebut, terdapat ornamen dengan bentuk lingkaran dan mandala yang disusun secara berulang, berfungsi sebagai loster untuk mengalirkan udara dan berwarna putih. Ornamen ini tidak termasuk dalam beberapa jenis ornamen flora menurut Gelebet, tetapi termasuk ornamen yang dibuat dengan keserasian dan keindahan bentuk.

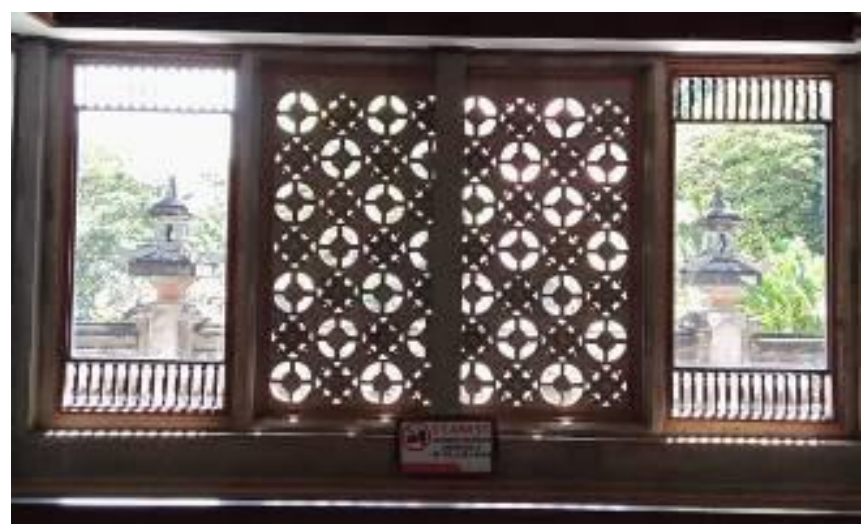

Gambar 17. Ornamen di dinding selatan atas pada bordes Sumber: Swari, 2020

Pada dinding bagian Timur Bordes, terdapat ornamen dengan bentuk para dewa yang sedang bersiap untuk mencari Tirtha Suci Kamandhalu. Ornamen ini berwarna putih dengan gambar para dewa mendominasi serta latar belakang pepohonan. Para Dewa digambarkan dengan menggunakan perhiasan di seluruh badan, sedangkan dinding bagian barat, yaitu diseberangnya menampilkan ornamen dengan bentuk para DetyaRaksasa yang juga sedang bersiap untuk mencari Tirtha Suci Kamandalu. Ornamen ini juga berwarna putih dengan gambar para Detya-Raksasa pada bagian depan serta pepohonan menjadi latar belakang. Para Detyaraksasa juga digambarkan lengkap dengan pakaian dan perhiasan. Kedua ornamen ini merupakan bagian dari cerita dalam Adi Parwa, yaitu pemutaran Gunung Mandhara. Filosofi dari ornamen ini adalah kesiapan para Dewa dan Detya-Raksasa untuk mencari Tirtha Suci Kamandalu.

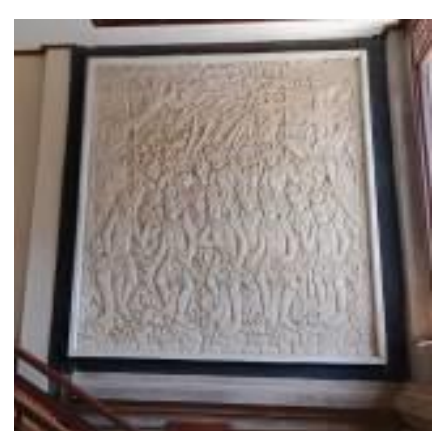

Gambar 18. Ornamen para Dewa di dinding timur bordes

Sumber: Swari, 2020

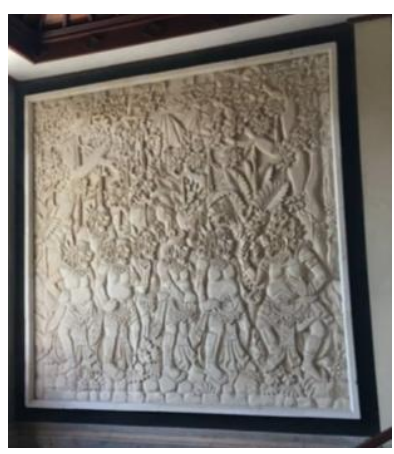

Gambar 19. Ornamen para Detya-Raksasa di dinding barat bordes Sumber: Utami, 2020

Pada railing tangga di bagian bordes juga terdapat ornamen dengan bentuk segi empat Panjang menyerupai tanaman dilengkapi bunga dan daun berwarna emas dan dasar berwarna merah. Ornamen ini terletak dikedua sisi tangga bagian bordes. Ornamen ini dapat dikategorikan sebagai patra Semblung karena terdapat gambar flora dengan daun dibawahnya. 


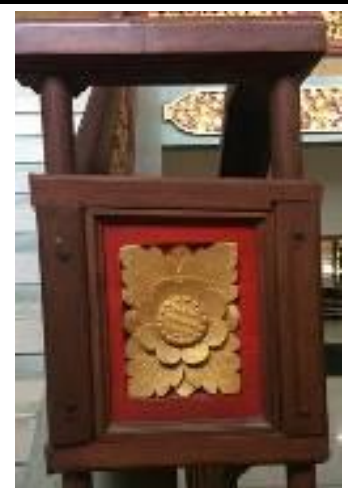

Gambar 20. Ornamen pada railing tangga di bordes

Sumber: Utami, 2020

Ornamen pada railing lantai atas menyerupai tanaman dengan bunga dan daun serta sulur yang digambarkan memajang dengan bentuk segi empat. Ornamen ini berwarna emas dengan dasar berwarna merah. Ornamen ini dapat dikelompokan dengan ornamen Patra Wangga jika dilihat dari bentuk bunga dan daunnya.

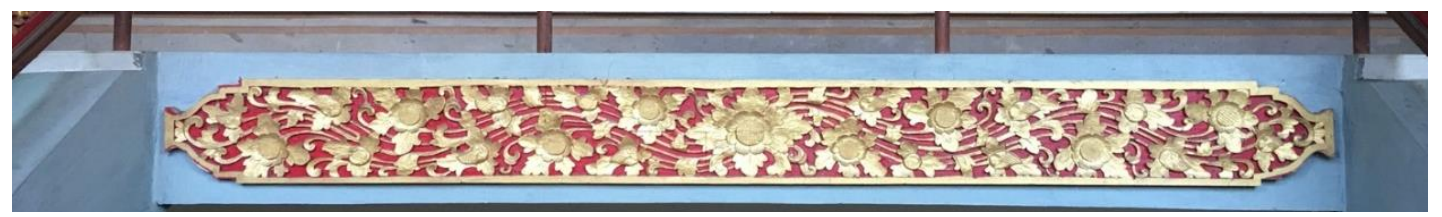

Gambar 21. Ornamen pada railing tangga di lantai atas Sumber: Utami, 2020

Setelah sampai pada lantai atas akan terlihat ornamen berupa gambar para dewa dan raksasa yang sedang bekerja sama dalam mencari Tirtha Suci Kamandhalu dengan masing-masing menarik ekor dan badan naga Basuki untuk memutar Gunung Mandhara. Ornamen ini terletak pada sisi utara dan selatan dari lantai atas sebelum masuk kedalam ruang pertunjukan dan memiliki warna putih. Ornamen ini memiliki nilai filosofis yaitu bekerja sama antara para Dewa dan Detya-Raksasa untuk mendapatkan Tirta Suci Kamandalu.

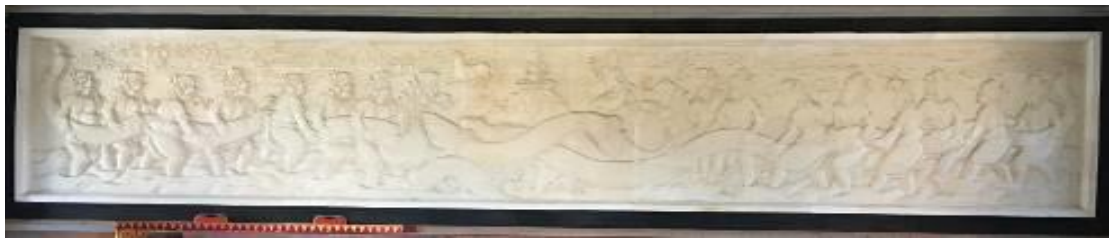

Gambar 22. Ornamen pada dinding lantai atas Sumber: Utami, 2020

Pada bagian bawah ornamen tadi terdapat juga ornamen berupa tanaman lengkap dengan bunga dan daun serta sulur yang berbentuk memanjang dan berwarna putih. Ornamen ini termasuk dalam ornament Patra Sari.

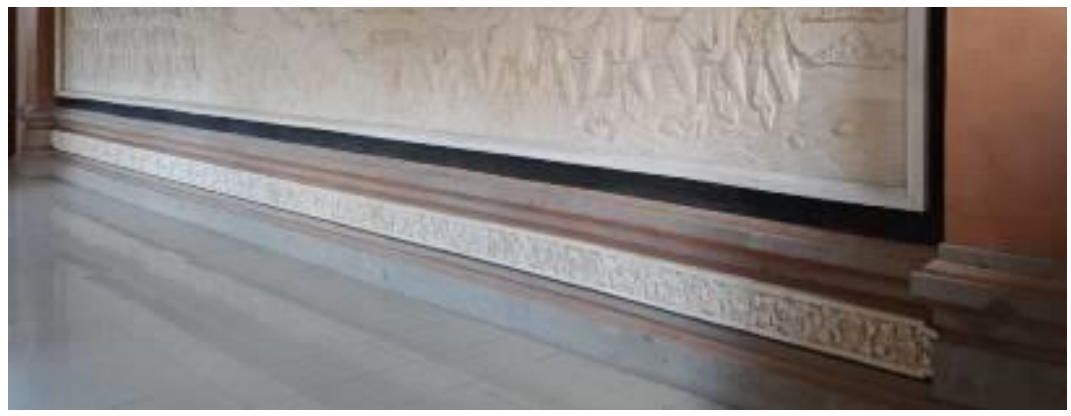

Gambar 23. Ornamen pada dinding berupa Patra Sari Sumber: Utami, 2020 
Pada ruangan tempat pertunjukan atau seminar, terdapat beberapa ornamen Arsitektur Tradisional Bali, baik yang memiliki filosofi cerita Pemutaran Gunung Mandhara ataupun sesuai dengan pakem Tardisional Bali yang telah ada. Pada bagian belakang panggung pertunjukan terdapat ornamen berupa para Dewa dan Detya-Raksasa yang sedang bekerjasama dalam memutar Gunung Mandhara, ornamen ini dibuat dengan media kayu yang ditempel didinding bagian belakang panggung, serta di dinding (aling-aling) tempat pintu keluar masuk (kori) seniman yang akan melakukan pertunjukan.
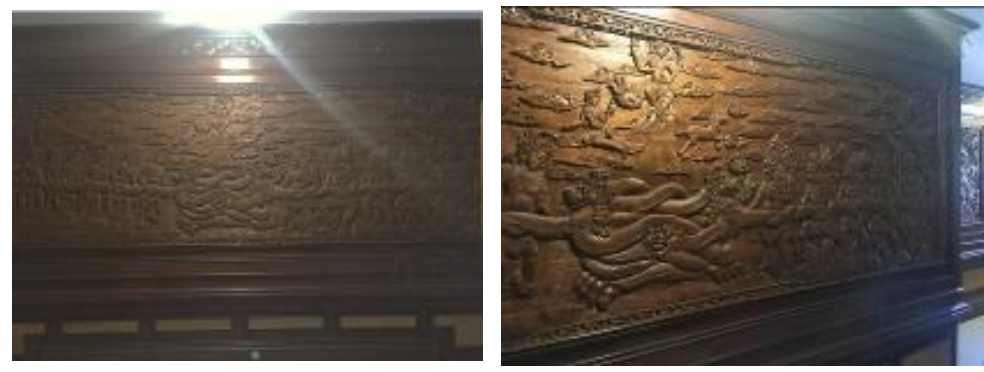

Gambar 24. Ornamen pada dinding belakang dan aling-aling panggung pertunjukan Sumber: Utami, 2020

Pada bagian kori panggung pertunjukan, terdapat ornamen dengan bentuk dua naga berwarna emas, yang merupakan perwujudan dari Naga Basuki dan Anantabhoga. Kedua naga ini masing-masing memiliki peran dalam pemutaran Gunung Mandhara, yaitu pematahan Gunung Mandhara dari dasarnya oleh Naga Anantabhoga dan Naga Basuki yang membelit patahan Gunung Mandhara sebelum ditarik oleh para Dewa dibagian ekor dan Detya-Raksasa pada bagian kepala (Suteja, 2017). Kori ini berjumlah 3 buah, dengan masing-masing kori memiliki ornamen dua ekor naga.
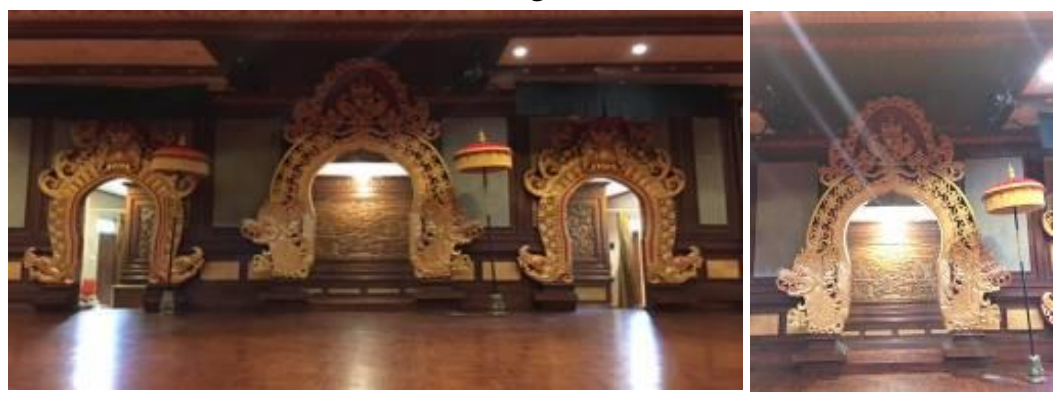

Gambar 25. Ornamen pada kori panggung Sumber: Utami, 2020

Pada bagian plafond ruang pertunjukan terdapat ornamen berbentuk wajik dengan flora didalamnya. Ornamen ini berwarna emas dengan dasar berwrna coklat dan merah, serta terletak di sepanjang list plank plafond. Ornamen ini termasuk Patra Mas-masan dengan bentuk yang lebih sederhana.
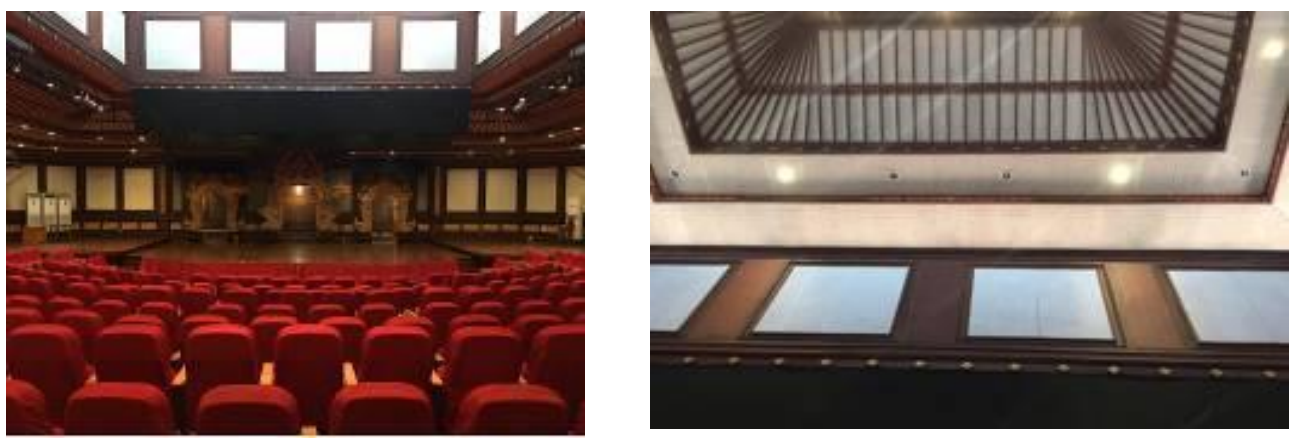

Gambar 26. Ornamen Patra Mas-masan pada plafond Sumber: Utami, 2020 
Pada dinding samping dan depan ruang pertunjukan terdapat beberapa ornamen dengan bentuk bunga mekar dengan daun-daun lebar yang divariasi dengan lengkung-lengkung. Ornamen ini berwarna emas dengan dasar berwarna merah. Ornamen ini termasuk pada bentuk Patra Wangga.

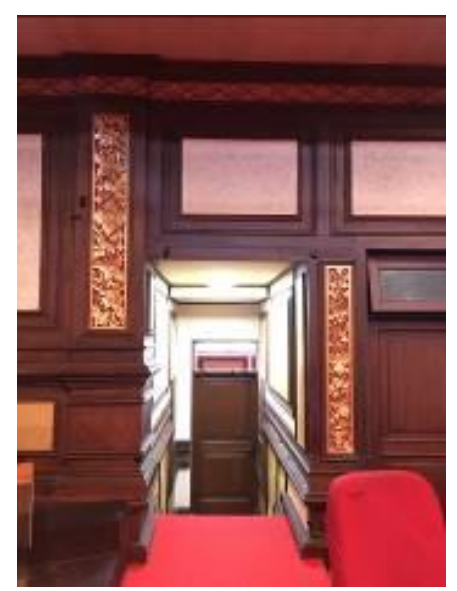

Gambar 27. Ornamen Patra Wangga pada dinding Sumber: Utami, 2020

\section{KESIMPULAN}

Pada interior bangunan Gedung Ksirarnawa ini terdapat dua jenis ornamen, satu adalah ornamen yang dibuat dengan nilai filosofis dari mitologi yang diyakini kebenaran dibaliknya (yaitu sesuai cerita pemutaran Gunung Mandhara), dan yang kedua adalah ornamen yang dibentuk untuk memperindah interior bangunan dan berciri khas Tradisonal Bali. Namun ornamen yang paling menonjol pada interior bangunan ini adalah ornamen dengan nilai filosofis dan mitologi cerita pemutaran Gunung Mandhara. Ornamen yang dibuat dengan filosofi dibaliknya adalah kekarangan berbentuk garuda, mandala yang berbentuk gunung, kolam, kori naga dan cerita para Dewa dan Detya-Raksasa yang sedang memutar Gunung Mandhara.

Ornamen yang berciri khas Tradisonal Bali adalah adanya Patra Wangga, Patra Sari, Patra Punggel dan Patra Mas-masan pada beberapa tempat di interior bangunan Gedung Ksirarnawa Perpaduan antara beberapa ornamen ini dapat mempertahankan ornamen Tradisional Bali sekaligus mengetahui cerita tentang perputaran Gunung Mandhara yang merupakan bagian dari Adi Parwa.

\section{Referensi}

Peraturan Daerah Provinsi Bali Nomor 5 Tahun 2005 tentang Persyaratan Arsitektur Bangunan Gedung, 1 (2005).

Bali, U. T. B. (2016). Taman Budaya Bali 2016.pdf. 1-74.

Gelebet, I Nyoman, I Wayan Megananda, I Made Y Negara, I. M. S. (1986). Arsitektur Tradisional Daerah Bali. Departemen Pendidikan dan Kebudayaan Provinsi Bali.

Iswati. (2016). Kajian Estetik dan Makna Simbolik Ornamen di Kompleks Makam Sunan Sendang Desa Sendangduwur Paciran Lamongan. Universitas Negeri Semarang.

Maharlika, F. (2018). STUDI MULTIKULTURAL PADA ORNAMEN BALI PEPATRAAN: PATRA CINA. 2(1), 67-77.

Moleong, L. J. (2017). Metodologi Penelitian Kualitatif Edisi Revisi (37i ed.). PT. Remaja Rosdakarya.

Paramadhyaksa, I. N. W. (2009). Info - Teknik Arsitektur Tradisional Bali. 10(1), 1-9.

Sunaryo, Aryo. 2009. Ornamen Nusantara. Semarang: Dahara Press. - Penelusuran Google. (n.d.). Retrieved July 14, 2020, from https://www.google.com/search?q=Sunaryo\%2C+Aryo.+2009.+Ornamen+ Nusantara.+Semarang\%3A+Dahara+Press.\&oq=Sunaryo\%2C+Aryo.+2009.+Ornamen+Nusantara.+Se marang\%3A+Dahara+Press.\&aqs $=$ chrome..69i57.648j0j7\&sourceid $=$ chrome\&ie $=\mathrm{UTF}-8$ 
Suparta, I. M. (2010). JENIS HIASAN TATAHAN BADE. Fakultas Seni Rupa Dan Desain ISI Denpasar, $8(1)$.

Suryada, I. G. A. B. (2014). Ornamen-ornamen Bermotif Kedok Wajah dalam Seni Arsitektur Tradisional Bali. Jurnal Sulapa, 1-11.

Suteja, I. W. (2017). Pengembangan Pengetahuan Sastra dan Budaya Sebagai Upaya Meningkatkan Pengetahuan Dan Apresiasi Terhadap Keragaman Budaya Bangsa. In I. K. Sudewa (Ed.), Seminar Nasional Sastra dan Budaya II (pp. 306-318). Fakultas Ilmu Budaya Universitas Udayana.

Swari, L. G. N. (2020). Dokumentasi Ksirsrnawa.

Utami, N. W. A. (2020). Dokumentasi Ksirarnawa.

Uthama, I. B. P. A. (2015). patra dalam ragam hias.pdf (pp. 44-47). Orti Media Informasi Ikatan Arsitek Indonesia Bali. 